\title{
COMPARATIVE STUDY OF CARDIOVASCULAR RESPONSE TO LMA INSERTION AND ENDOTRACHEAL TUBE INTUBATION
}

Pachaimuthu Elango ${ }^{1}$, Gurusamy Sivakumar², Vivekanandan Balasubramaniaguhan ${ }^{3}$, Krishnamurthi Anitha $^{4}$, Anbu Srinivasan $^{5}$

1 Professor, Department of Anaesthesiology, KAP Viswanatham Government Medical College/MGM Govt. Hospital, Trichy.

${ }^{2}$ Associate Professor, Department of Anaesthesiology, KAP Viswanatham Government Medical College/MGM Govt. Hospital, Trichy.

${ }^{3}$ Assistant Professor, Department of Anaesthesiology, KAP Viswanatham Government Medical College/MGM Govt. Hospital, Trichy.

${ }^{4}$ Assistant Professor, Department of Anaesthesiology, KAP Viswanatham Government Medical College/MGM Govt. Hospital, Trichy.

${ }_{5}^{5}$ Associate Professor, Department of Orthopaedics, KAP Viswanatham Government Medical College/MGM Govt. Hospital, Trichy.

\section{ABSTRACT}

\section{BACKGROUND}

Tracheal intubation is performed routinely during general anaesthesia to secure the airway, to facilitate ventilation of the lungs, for control of partial pressures of oxygen and carbon dioxide in arterial blood. Laryngoscopy and intubation are associated with tachycardia, hypertension and arrhythmias. Placement of LMA is effective in securing the airway. Its insertion does not require Laryngoscopy and its placement is less stimulating and produces less catecholamine release; hence, there is no tachycardia, hypertension and arrhythmias.

The aim of the study is to analyse the cardiovascular response to LMA and ETT insertion.

\section{MATERIALS AND METHODS}

This study was done to evaluate the cardiovascular response to intubation following insertion of LMA and ETT. This is a prospective, non-randomised, clinical study of 110 patients admitted to KAP Viswanatham Medical College Hospital, Trichy, during 2002 - 04 to undergo elective surgical procedures. Overall, 110 patients were found to have the satisfying criteria and they were all included in the study and alternatively allotted to each group, hence the sample size is 110 . The patients were in the age group of 14 - 70 years.

\section{RESULTS}

Two sample student's ' $t$ ' test and standard error of mean test were used for statistical analysis of the parameters obtained in the study. The following are the results obtained in our study. The heart increased by $15.54 \%$ following endotracheal intubation and by $9.91 \%$ following laryngeal mask insertion. The systolic blood pressure showed an increase of $14.13 \%$ in endotracheal group and $4.88 \%$ in laryngeal mask group. The diastolic blood pressure increased by $17.73 \%$ in endotracheal group and $27.27 \%$ in laryngeal mask group. The rate pressure product increased by $31.26 \%$ following endotracheal intubation and $14.20 \%$ following laryngeal mask insertion. The incidence of premature ventricular contraction is $9.09 \%$ following endotracheal intubation and $3.64 \%$ following laryngeal mask airway insertion.

\section{CONCLUSION}

This study shows that a considerably less cardiovascular response is produced by insertion of the laryngeal mask airway compared with direct Laryngoscopy and Endotracheal intubation. The laryngeal mask airway may be useful in situations where the pressor response to endotracheal intubation should be avoided, for example during induction of anaesthesia in an hypertensive patient.

\section{KEYWORDS}

LMA, Endotracheal Tube, Intubation, Haemodynamic Response.

HOW TO CITE THIS ARTICLE: Elango P, Sivakumar G, Balasubramaniaguhan V, et al. Comparative study of cardiovascular response to LMA insertion and endotracheal tube intubation. J. Evolution Med. Dent. Sci. 2017;6(45):3548-3553, DOI: 10.14260/Jemds/2017/764

\section{BACKGROUND \\ Tracheal intubation is performed routinely during general anaesthesia to secure the airway, to facilitate ventilation of the lungs, for control of partial pressures of oxygen and carbon dioxide in arterial blood. Laryngoscopy and intubation are associated with tachycardia, hypertension and arrhythmias. ${ }^{1}$}

Financial or Other, Competing Interest: None.

Submission 28-02-2017, Peer Review 24-05-2017,

Acceptance 30-05-2017, Published 05-06-2017.

Corresponding Author:

Dr. Gurusamy Sivakumar,

5/7 Race Course Road,

Professor's Colony,

Trichy - 620020.

E-mail: drsivakumar08@yahoo.com

DOI: $10.14260 /$ jemds/2017/764

\section{(c) (i) $(9)$}

Placement of LMA is effective in securing the airway. ${ }^{2}$ Its insertion does not require Laryngoscopy and its placement is less stimulating and less catecholamine release; hence, there is no tachycardia, hypertension and arrhythmias. ${ }^{3}$ The aim of the study is to analyse the cardiovascular response to LMA and ETT insertion.

\section{MATERIALS AND METHODS}

This study was done to evaluate the cardiovascular response to intubation following insertion of LMA and ETT. This is a prospective, non-randomised clinical study of 110 patients admitted to KAP Viswanatham Government Medical College Hospital, Trichy during 2002 - 04 to undergo elective surgical procedures. The patients were in the age group of $14-70$ years. Preoperative evaluation was done in all patients including assessment of the airway. Investigations include 
Urine albumin, Sugar, Hb, Blood urea, Sugar, Creatinine, XRay chest and ECG.

Exclusion criteria include hypertension, bronchial asthma, cerebrovascular disease, cardiovascular disease and blood pressure $>$ than $140 / 90 \mathrm{mmHg}, \mathrm{Hb}<8 \mathrm{gm} \%$, patients with ECG showing evidence of ischaemic heart disease and rhythm disturbance.

The estimated sample size was found to be 104 (52 in each group) by using a study done by $\mathrm{N}$ Braude et al, where the mean (SD) systolic Blood Pressure was found to be 114.5 (2.54) and 116.0 (2.88) in Tracheal tube group and Laryngeal mask group respectively at 5 minutes. Finally, 110 patients were found to have the satisfying criteria and they were all included in the study and alternatively allotted to each group. All the patients included for the study were advised nil oral after $10 \mathrm{pm}$ the night before study. Premedication in the ward include T. Diazepam $0.2 \mathrm{mg} / \mathrm{kg}$ orally, T. Ranitidine $3 \mathrm{mg} / \mathrm{kg}$ orally, T. Metoclopramide $0.2 \mathrm{mg} / \mathrm{kg}$ orally at $10 \mathrm{pm}$ the night before surgery. All patients were given premedication of Inj. Pentazocine $0.4 \mathrm{mg} / \mathrm{kg}$ (not exceeding $30 \mathrm{mg}$ totally) and atropine $10 \mu \mathrm{g} / \mathrm{kg}$ (not exceeding $0.6 \mathrm{mg}$ total dose) intramuscularly 45 minutes to 70 minutes before induction of anaesthesia.

Intravenous access was established on arrival in the operation theatre with continuous monitoring of ECG, Blood pressure and $\mathrm{SpO}_{2}$. Patients were randomly allocated to either ETT group or LMA group. Appropriate size ETT or LMA was kept ready for that patient. Patients were reassured and a stabilisation period of 5 minutes was allowed. Pre-induction baseline heart rate and blood pressure were recorded. Preoxygenation was done with $100 \%$ oxygen for 3 minutes. Anaesthesia was induced with Pentazocine $0.2 \mathrm{mg} / \mathrm{kg}$ and 2.5\% Thiopentone sodium $4-5 \mathrm{mg} / \mathrm{kg}$ until eyelash reflex was lost. This was followed by muscle paralysis with 1.5 $\mathrm{mg} / \mathrm{kg}$ Succinylcholine and patients were ventilated with $100 \% \mathrm{O}_{2}$ using facemask. After complete paralysis was achieved, Laryngoscopy was performed with standard intubating pillow. Endotracheal intubation was done with Lignocaine jelly smeared to cuff of appropriate size ET tube with cuff inflated to achieve a seal. Positive pressure ventilation was commenced with nitrous oxide and oxygen using Bain's circuit.

In LMA group patients, the fully deflated Lignocaine smeared LMA was inserted after complete paralysis with Succinylcholine as per the technique described by Brain. The neck was flexed with a pillow under the head with a slightly extended head, the laryngeal mask was held like a pen and inserted by pressing it against the hard palate and was advanced into the oral cavity with the help of gloved hand and was guided into the posterior pharyngeal wall as deeply as possible till a resistance was felt. The cuff was inflated with appropriate amount of air as recommended to produce a complete seal. Positive pressure ventilation was commenced with nitrous oxide and oxygen using Bain's circuit. Vecuronium $0.1 \mathrm{mg} / \mathrm{kg}$ was administered intravenously.

Patients in whom more than one attempt was made to intubate the trachea or insert an LMA were excluded from the study. No other medications were administered or procedures performed during the 10 minutes data collection period. The study parameters monitored were Heart rate, Systolic blood pressure and Diastolic blood pressure at 0- minute and every minute thereafter up to 5 minutes and on the $10^{\text {th }}$ minute.

Reversal was done at the end of surgery with Neostigmine $40 \mu \mathrm{g} / \mathrm{kg}$ and atropine $20 \mu \mathrm{g} / \mathrm{kg}$.

\section{Statistical Analysis}

The data were entered in Excel Sheet and checked for any errors. Analysis was done using Frequencies; Proportions were calculated for qualitative variables. Mean and standard deviation used for quantitative variables. Independent sample ' $\mathrm{t}$ ' test and paired ' $\mathrm{t}$ ' tests were performed to compare the means of two groups. A probability value $(\mathrm{p})<0.05$ was regarded as statistically significant.

\section{RESULTS}

\begin{tabular}{|c|c|c|}
\hline $\begin{array}{c}\text { Age in } \\
\text { Years }\end{array}$ & $\begin{array}{c}\text { LMA Group } \\
(\mathbf{n = 5 5 )}\end{array}$ & $\begin{array}{c}\text { ETT Group } \\
\text { (n = 55) }\end{array}$ \\
\hline $11-20$ & 11 & 4 \\
\hline $21-30$ & 23 & 21 \\
\hline $31-40$ & 11 & 10 \\
\hline $41-50$ & 6 & 14 \\
\hline $50-60$ & 2 & 5 \\
\hline $60-70$ & 2 & 1 \\
\hline Mean & 30.13 & 36.03 \\
\hline SD & 11.07 & 7.23 \\
\hline \multicolumn{3}{|c|}{ Table 1. Age Incidence } \\
\hline
\end{tabular}

\begin{tabular}{|c|c|c|}
\hline & $\begin{array}{c}\text { LMA Group } \\
(\mathbf{n = 5 5 )}\end{array}$ & $\begin{array}{c}\text { ETT Group } \\
(\mathbf{n = 5 5 )}\end{array}$ \\
\hline Male & 36 & 40 \\
\hline Female & 19 & 15 \\
\hline \multicolumn{2}{|c|}{ Table 2. Sex Incidence } \\
\hline
\end{tabular}

\begin{tabular}{|c|c|c|}
\hline & $\begin{array}{c}\text { LMA Group } \\
(\mathbf{n}=\mathbf{5 5})\end{array}$ & $\begin{array}{c}\text { ETT Group } \\
(\mathbf{n}=\mathbf{5 5})\end{array}$ \\
\hline Mean & 47.67 & 46.98 \\
\hline SD & 7.23 & 7.89 \\
\hline \multicolumn{2}{|c|}{ Table 3. Weight in KG } \\
\hline
\end{tabular}

\begin{tabular}{|c|c|c|c|}
\hline Time & $\begin{array}{l}\text { LMA Group } \\
\text { Mean } \pm \text { SD }\end{array}$ & $\begin{array}{l}\text { ETT Group } \\
\text { Mean } \pm \text { SD }\end{array}$ & \begin{tabular}{|c|}
$\mathbf{P}$ \\
value
\end{tabular} \\
\hline $\begin{array}{l}\text { Baseline (Pre- } \\
\text { Induction) }\end{array}$ & $98.71 \pm 2.69$ & $98.15 \pm 2.55$ & $>0.05$ \\
\hline Post-Induction & $\mathrm{Q}$ & 8 & 005 \\
\hline $\begin{array}{l}\text { Immediately after } \\
\text { Intubation or } \\
\text { Insertion } \\
\text { (Zero Minute) }\end{array}$ & $108.5 \pm 2.16$ & $109.0 \pm 2.19$ & $>0.05$ \\
\hline 1 Minute & 2.32 & 2.71 & $>0.05$ \\
\hline $2 \mathrm{M}$ & $102.2 \pm 2.24$ & $113.0 \pm 2.50$ & $<0.05^{*}$ \\
\hline $3 \mathrm{M}$ & 97.7 & 2.51 & $<0.05^{*}$ \\
\hline $4 \mathrm{M}$ & 2.18 & \pm 2.24 & $<0.05^{*}$ \\
\hline 5 Minute & $93.45 \pm 2.12$ & $101.3 \pm 2.09$ & $<0.05^{*}$ \\
\hline 10 Minutes & $89.22 \pm 1.85$ & $94.47 \pm 1.89$ & $<0.05^{*}$ \\
\hline \multicolumn{4}{|c|}{$\begin{array}{l}\text { Table 4. Changes in Heart Rate at Various Time Intervals } \\
\text { following Endotracheal Intubation and Laryngeal Mask } \\
\text { Insertion }\end{array}$} \\
\hline
\end{tabular}

The above table shows the mean heart rate (beats/min) at various time intervals. The values are expressed as Mean \pm Standard Deviation. $\mathrm{P}$ value of Independent sample ' $\mathrm{t}$ ' test given. *Significant $\mathrm{P}$ value. 
There was no significant difference in heart rates in baseline (pre-induction) values between the two groups. Heart rate increased above the baseline values in both the groups after induction (post-induction), but there was no significant difference between the two groups.

In the laryngeal mask group, heart rate values were significantly higher $(\mathrm{P}<0.05)$ than the baseline values at 0 minute and 1 minute. The highest heart rate values were seen at 0 minute. The heart rate began to fall below the baseline values from 3 minutes.

In the Endotracheal tube group, the heart rate remained significantly elevated $(\mathrm{P}<0.05)$ above the baseline values up to 4 minutes from the time of intubation and maximum increase in heart rate was seen at 1 minute. There was no significant difference in heart rate between the two groups at 0 minute and 1 minute. At all other times, the heart rate remained significantly higher $(\mathrm{P}<0.05)$ in the Endotracheal group.

\begin{tabular}{|c|c|c|}
\hline Time & $\begin{array}{c}\text { LMA Group } \\
\text { (\%) }\end{array}$ & $\begin{array}{c}\text { ETT Group } \\
\text { (\%) }\end{array}$ \\
\hline Post-Induction & +1.61 & +1.48 \\
\hline $\begin{array}{c}\text { Immediately after Intubation } \\
\text { Insertion } \\
(0 \text { minute) }\end{array}$ & +9.91 & +11.05 \\
\hline 1 minute & +8.80 & +15.54 \\
\hline 2 minutes & +3.54 & +15.13 \\
\hline 3 minutes & -1.01 & +11.87 \\
\hline 4 minutes & -3.09 & +7.39 \\
\hline 5 minutes & -5.33 & +3.21 \\
\hline 10 minutes & -9.61 & -3.75 \\
\hline Table 5. Percentage Change in Heart Rate from \\
Baseline at various Time Intervals \\
\hline
\end{tabular}

The maximum percentage increase in heart rate following endotracheal intubation was $15.54 \%$, while maximum percentage increase following laryngeal mask insertion was 9.91\%.

\begin{tabular}{|c|c|c|}
\hline Time & $\begin{array}{l}\text { LMA Group } \\
\text { Mean } \pm \text { SD }\end{array}$ & $\begin{array}{l}\text { ETT Group } \\
\text { Mean } \pm \text { SD }\end{array}$ \\
\hline $\begin{array}{c}\text { Baseline } \\
\text { (Pre-Induction) }\end{array}$ & $127.0 \pm 1.54$ & $128.8 \pm 1.82$ \\
\hline Post-Induction & $114.5 \pm 1.84$ & $116.6 \pm 1.72$ \\
\hline $\begin{array}{c}\text { Immediately after } \\
\text { Intubation or } \\
\text { Insertion } \\
\text { (Zero Minute) } \\
\end{array}$ & $132.0 \pm 1.84^{*}$ & $142.5 \pm 2.18^{*}$ \\
\hline 1 Minute & $133.2 \pm 2.01^{*}$ & $147.0 \pm 2.16^{*}$ \\
\hline 2 Minutes & $127.9 \pm 2.12+$ & $145.9 \pm 2.32^{*}$ \\
\hline 3 Minutes & $123.7 \pm 1.94+$ & $138.8 \pm 2.41^{*}$ \\
\hline 4 Minutes & $120.0 \pm 1.54+$ & $135.7 \pm 2.17^{*}$ \\
\hline 5 Minutes & $119.3 \pm 1.44+$ & $130.6 \pm 1.99$ \\
\hline 10 Minutes & $117.8 \pm 1.41+$ & $126.4 \pm 1.46$ \\
\hline \multicolumn{3}{|c|}{$\begin{array}{c}\text { Table 6. Changes in Systolic Blood Pressure at various } \\
\text { Time Intervals following Endotracheal Intubation and } \\
\text { Laryngeal Mask Insertion }\end{array}$} \\
\hline
\end{tabular}

The above table shows the mean heart rate at various time intervals. The values are expressed as mean \pm standard error of mean. $P$ values are also given.

$*(\mathrm{P}<0.05)$ vs. baseline

$+\mathrm{P}(<0.05)$

(ETT Group vs. LMA Group)
There was no significant difference in systolic blood pressure between the two groups in the pre-induction period. After induction, there was a fall in systolic blood pressure in both the groups and there was no significant difference between the two groups. Immediately, after endotracheal intubation or laryngeal mask insertion there was a significant increase in systolic blood pressure in both the groups. The maximum increase in systolic blood pressure occurred at one minute in both the groups. In the laryngeal mask group, significant increase $(\mathrm{P}<0.05)$ in systolic blood pressure above the baseline was seen at 0 minute and 1 minute from insertion.

From the third minute, the systolic blood pressure began to fall below the baseline value. In the endotracheal tube group, significant increase $(\mathrm{P}<0.05)$ in systolic blood pressure above the baseline was seen up to 4 minutes and at the tenth minute it was seen to be below the baseline value. At all times, the systolic blood pressure remained significantly higher $(\mathrm{P}<0.05)$ in the Endotracheal group.

\begin{tabular}{|c|c|c|}
\hline Time & $\begin{array}{c}\text { LMA Group } \\
(\%)\end{array}$ & $\begin{array}{c}\text { ETT Group } \\
\text { (\%) }\end{array}$ \\
\hline Post-Intubation & -9.84 & -9.47 \\
\hline $\begin{array}{c}\text { Immediately after Intubation } \\
\text { Insertion } \\
\text { (0 Minute) }\end{array}$ & +3.94 & +10.64 \\
\hline 1 minute & +4.88 & +14.13 \\
\hline 2 minutes & +0.71 & +13.28 \\
\hline 3 minutes & -2.60 & +7.76 \\
\hline 4 minutes & -5.51 & +5.36 \\
\hline 5 minutes & -6.06 & +1.40 \\
\hline 10 minutes & -7.24 & -1.86 \\
\hline $\begin{array}{c}\text { Table 7. Percentage Change in Systolic Blood Pressure } \\
\text { from Baseline at various Time Intervals }\end{array}$ \\
\hline
\end{tabular}

The maximum percentage increase in systolic blood pressure following endotracheal intubation was $14.13 \%$. While the maximum percentages increase following laryngeal mask insertion was only $4.88 \%$. In the laryngeal mask group, the diastolic blood pressure showed an increase from 0 minute and it remained significantly higher $(\mathrm{P}<0.05)$ than the baseline value up to 2 minutes. In the endotracheal group, the diastolic blood pressure showed an increase from 0 minute and it remained significantly higher $(\mathrm{P}<0.05)$ than the baseline value up to 4 minutes.

The diastolic blood pressure remained significantly higher $(\mathrm{P}<0.05)$ in the endotracheal group compared to the laryngeal mask airway group at all times other than at 1 minute.

\begin{tabular}{|c|c|c|}
\hline Time & LMA Group (\%) & ETT Group (\%) \\
\hline Post-Intubation & -6.82 & -7.78 \\
\hline $\begin{array}{c}\text { Immediately after } \\
\text { Intubation or } \\
\text { Insertion ( } 0 \text { minute) }\end{array}$ & +10.47 & +11.8 \\
\hline 1 minute & +27.27 & +17.73 \\
\hline 2 minutes & +9.42 & +14.43 \\
\hline 3 minutes & +3.65 & +9.58 \\
\hline 4 minutes & +1.52 & +5.84 \\
\hline 5 minutes & +0.31 & +2.39 \\
\hline 10 minutes & -0.05 & -1.49 \\
\hline
\end{tabular}


The minimal increase in the diastolic blood pressure following laryngeal mask insertion was by $27.27 \%$ which occurred at one minute after insertion, while the maximal increase following endotracheal intubation was $17.73 \%$ which also occurred at one minute.

\begin{tabular}{|c|c|c|}
\hline Time & $\begin{array}{c}\text { LMA Group } \\
\text { Mean } \pm \text { SD }\end{array}$ & $\begin{array}{c}\text { ETT Group } \\
\text { Mean } \pm \text { SD }\end{array}$ \\
\hline $\begin{array}{c}\text { Baseline } \\
\text { (Pre-Induction) }\end{array}$ & $12577.02 \pm 04.8$ & $12732.87 \pm 430.2$ \\
\hline Post-Induction & $11448.16 \pm 307.5$ & $11651.82 \pm 336.1$ \\
\hline $\begin{array}{c}\text { Immediately } \\
\text { after } \\
\text { Intubation or } \\
\text { Insertion } \\
\text { (Zero Minute) }\end{array}$ & $14358.98 \pm 383.5 *+$ & $15568.25 \pm 424.1 *$ \\
\hline 1 Minute & $14363.31 \pm 425.2 *+$ & $16713.96 \pm 491.5 *$ \\
\hline 2 Minutes & $13121.02 \pm 396.0+$ & $16526.69 \pm 470.7 *$ \\
\hline 3 Minutes & $12106.36 \pm 355.2+$ & $15270.91 \pm 447.8 *$ \\
\hline 4 Minutes & $11454.05 \pm 275.8+$ & $14329.75 \pm 402.8 *$ \\
\hline 5 Minutes & $11114.44 \pm 257.8+$ & $13268.00 \pm 386.7$ \\
\hline 10 Minutes & $10488.84 \pm 235.9+$ & $11983.85 \pm 317.1$ \\
\hline $\begin{array}{c}\text { Table 9. Changes in Rate Pressure Product at various Time } \\
\text { Intervals following Endotracheal Intubation and } \\
\text { Laryngeal Mask Insertion }\end{array}$ \\
\hline \multicolumn{3}{|c|}{}
\end{tabular}

The above table shows the rate pressure product at various time intervals. Rate pressure product is expressed as beats $\mathrm{mmHg} /$ minute. The values are expressed as mean \pm standard error of mean. The $P$ values are also given. $*(\mathrm{P}<0.05)$ vs. baseline $+\mathrm{P}(<0.05)$

(ETT Group vs. LMA Group)

There was no significant difference between the two groups in the rate pressure product in the pre-induction period. After induction, there was a fall in rate pressure product below the baseline values in both the groups and there was no significant difference between the two groups. Rate pressure product began to increase significantly $(\mathrm{P}<$ 0.05) above the baseline values in both the groups immediately after endotracheal intubation or laryngeal mask insertion. The maximum increase was seen at the first minute in both the groups.

In the laryngeal mask group, the significant rise $(\mathrm{P}<0.05)$ in rate pressure product was seen at 0 minute and 1 minute above the baseline value. In the endotracheal tube group, the rise in rate pressure product above the baseline value was seen from the time of intubation and it remained significantly elevated $(\mathrm{P}<0.05)$ up to 4 minutes above the baseline value.

At all times, the rate pressure product remained significantly higher $(\mathrm{P}<0.05)$ in the endotracheal tube group compared to the laryngeal mask group.

\begin{tabular}{|c|c|c|}
\hline Time & $\begin{array}{c}\text { LMA } \\
\text { Group (\%) }\end{array}$ & $\begin{array}{c}\text { ETT } \\
\text { Group (\%) }\end{array}$ \\
\hline Post-Intubation & -8.98 & -8.49 \\
\hline $\begin{array}{l}\text { Immediately after Intubation } \\
\text { or Insertion ( } 0 \text { minute) }\end{array}$ & +14.17 & +22.27 \\
\hline 1 minute & +14.20 & +31.26 \\
\hline 2 minutes & +4.33 & +29.80 \\
\hline 3 minutes & -3.74 & +19.93 \\
\hline 4 minutes & -8.93 & +12.54 \\
\hline 5 minutes & -11.63 & +4.20 \\
\hline 10 minutes & -16.60 & -5.89 \\
\hline \multicolumn{3}{|c|}{$\begin{array}{l}\text { Table 10. Percentage Change in Rate Pressure Product } \\
\text { from Baseline at various Time Intervals }\end{array}$} \\
\hline
\end{tabular}

The maximum increase in rate pressure product following endotracheal intubation was by $31.26 \%$ which occurred in the first minute following intubation, while the maximum increase following laryngeal mask insertion was by $14.20 \%$ which also occurred one minute after insertion.

\begin{tabular}{|c|c|c|}
\hline & Group - LMA & Group - ETT \\
\hline $\begin{array}{c}\text { Ventricular Premature } \\
\text { Contractions }\end{array}$ & 2 & 5 \\
\hline $\begin{array}{c}\text { Table 11. Incidence of Electrocardiographic Changes } \\
\text { in the First 10 Minutes following Endotracheal } \\
\text { Intubation/Laryngeal Mask Insertion }\end{array}$ \\
\hline
\end{tabular}

In LMA Group, out of 55 patients studied 2 patients (3.64\%) showed ventricular premature contractions. In ETT Group of the 55 patients studied, 5 patients (9.09\%) showed ventricular premature contractions and sinus tachycardia was commonly seen in both the groups.

\section{DISCUSSION}

Hypertension and tachycardia have been recognised since the 1950 s as commonly associated with intubation under light Anaesthesia. ${ }^{4}$ Studies have shown that they are accompanied by corresponding elevations of circulating concentrations of catecholamine. 5 The transient circulatory response evoked by direct laryngoscopy and intubation are probably innocuous in patients with normal circulatory system. The circulatory system may be exaggerated in patients with pre-existing hypertension. ${ }^{6}$ Furthermore, these responses may jeopardise tissue viability in patients with coronary artery disease, valvular heart disease or intracranial tension. ${ }^{7}$

This hypertension and tachycardia have far reaching consequences on cardiovascular system. Myocardial oxygen consumption has been correlated with the product of heart rate and peak systolic pressure. This has been termed as the rate pressure product. The left ventricular wall tension is directly related to the myocardial oxygen consumption.

\begin{tabular}{|c|}
\hline LV radius $X$ LV peak systolic pressure \\
LV wall tension $=$ wall thickness \\
\hline
\end{tabular}

A major determinant of myocardial oxygen consumption.

An increase in systolic blood pressure may cause an increase in myocardial oxygen demand. However, it may also concomitantly improve myocardial oxygenation by increasing coronary perfusion pressure. In contrast increase in heart rate is unlikely to improve myocardial oxygen balance since it presents a dual threat, increasing heart rate increases myocardial oxygen demand and magnifies the problem by decreasing the diastolic duration, thereby impinging upon the time available for coronary perfusion.

Rate pressure product may be an important predictor of intraoperative myocardial ischaemic injury. ${ }^{8}$ Levels of rate pressure product in excess of 20,000 are more commonly associated with angina and myocardial ischaemia.

\section{Changes in Heart Rate}

The present study shows that there is an increase in heart rate following laryngeal mask insertion or endotracheal intubation. ${ }^{4,9}$ The heart rate remained significantly elevated $(\mathrm{P}<0.05)$ up to 1 minute following laryngeal mask insertion in contrast to 4 minutes following endotracheal intubation 
and these heart rate values are significantly greater than the laryngeal mask group $(\mathrm{P}<0.05)$ through this 4 minutes period.

The findings are similar to that of Yoshitaka Fujii et al, F. Watcha et al, whereas Wilson has showed that increase in heart rates were similar in both endotracheal intubation and laryngeal mask airway insertion $(26.6 \%$ and $25.7 \%)$. Shribman et al showed that there is $19 \%$ increase in heart rate following laryngoscopy.6,10

Present study shows that there is an increase in heart rate following laryngeal mask insertion (9.91\%) or endotracheal intubation $(15.54 \%)$. The heart rate remains significantly elevated $(\mathrm{P}<0.05)$ above the baseline values for 1 minute following laryngeal mask insertion. ${ }^{11}$ Following laryngoscopy and intubation the heart rate remained significantly elevated $(\mathrm{P}<0.05)$ above the baseline for 4 minutes.

\section{Changes in Systolic Blood Pressure}

Our study shows that there is an increase in systolic blood pressure following laryngeal mask insertion (4.88\%) or endotracheal intubation (14.13\%). The systolic blood pressure remained significantly elevated $(\mathrm{P}<0.05)$ up to 1 minute following laryngeal mask insertion. ${ }^{11}$ Following laryngoscopy and intubation, the significant rise $(\mathrm{P}<0.05)$ in systolic blood pressure persisted up to 4 minutes and these are significantly higher than the corresponding values of laryngeal mask group. ${ }^{12}$

Yoshitaka Fujii et al have shown that the systolic blood pressure following intubation is significantly higher than that following laryngeal mask insertion. Wilson et al have observed a 51.3\% increase in systolic blood pressure following laryngoscopy and intubation versus $22.9 \%$ following laryngeal mask insertion. Shribman et al have shown that there is a $36 \%$ increase in systolic pressure following laryngoscopy with or without intubation.13,14 Griffin et al have shown that that there is no significant difference in systolic blood pressure between endotracheal intubation and laryngeal mask insertion. Braude et al also have found no significant difference in pressor response between endotracheal intubation and laryngeal mask insertion. ${ }^{15}$

\section{Changes in Diastolic Blood Pressure}

This study has shown that there is an increase in diastolic blood pressure at one minute following laryngeal mask insertion $(27.27 \%)$ or endotracheal intubation $(17.73 \%)$. Statistically, there is no significant difference between these two values. At all other times, the diastolic blood pressure in the laryngeal mask group remained significantly lower than the endotracheal group. The rise in diastolic blood pressure above the baseline was significant $(\mathrm{P}<0.05)$ up to one minute following laryngeal mask insertion values and up to 4 minutes following endotracheal intubation. Wilson et al have shown that diastolic blood pressure following endotracheal intubation raised by $53.2 \%$ versus $27.7 \%$ following laryngeal mask insertion.

\section{Changes in Rate Pressure Product}

This study shows that there is an increase in rate pressure product following LMA insertion $(14.20 \%)$ or endotracheal intubation $(31.26 \%)$. The rate pressure product remained significantly elevated above the baseline value up to 1 minute following LMA insertion. Following endotracheal intubation, rate pressure product remained significantly elevated above the baseline value up to 4 minutes and they are significantly higher than the corresponding values following laryngeal mask insertion.

The mechanism of circulatory response to Laryngoscopy and intubation has been studied by various persons. ${ }^{6}$ Stoelting demonstrated that increased duration of laryngoscopy caused a progressive increase in mean arterial pressure. P. Mills and T. Pookin, in their study have shown that the cricoid pressure applied during intubation does not alter the pressor response significantly. MJL Bucx, RTM Vangeel and Scheck have measured the forces applied during laryngoscopy and they have shown that these forces are only weakly related to the cardiovascular changes, whereas tracheal intubation has a major influence. They concluded that tracheal intubation causes more cardiovascular changes than laryngoscopy. ${ }^{16}$ JE Smith, in his study has shown that the cardiovascular changes are more pronounced during fibreoptic tracheal intubation than during direct laryngoscopy with a Macintosh laryngoscope and intubation. Earlier studies have shown that anterior pharynx is particularly sensitive and stimulation of this region resulted in greater sympathetic reaction. ${ }^{17}$ But in fibreoptic intubation, pressure on this anterior pharynx is not present, yet there is severe cardiovascular response in this compared to the standard laryngoscopic intubation. ${ }^{18}$ The afferent stimulation of the larynx results in an imbalance between sympathetic and vagal stimulation leading to hypertension, tachycardia and catecholamine release.

Overzealous use of deep anaesthesia, local anaesthetics, depressant drugs or vasodilators in an attempt to prevent circulatory changes caused by direct laryngoscopy and endotracheal intubation may ultimately introduce more hazard than the response they were intended to attenuate.16,18,19 Because the insertion of LMA does not warrant the use of laryngoscopy and it does not invade the glottis, the circulatory response to its insertion is less compared to endotracheal intubation. Yet a limited afferent stimulation of pharynx and larynx due to the tissue tension in the supraglottic region does occur resulting in a smaller rise in heart rate and blood pressure.

This study demonstrates that the use of LMA is associated with significantly reduced haemodynamic variations than endotracheal intubation.

One hundred and ten patients admitted to KAP Viswanatham Government Medical College Hospital, Trichy to undergo various surgical procedures were studied. The patients were divided into two groups of fifty-five each and all of them belonged to ASA status-I. The cardiovascular response to either laryngoscopy and intubation or laryngeal mask intubation was studied.

All the patients were given the drugs that are routinely employed in the hospital for premedication, induction and muscle paralysis. All of them were given diazepam, ranitidine and metoclopramide orally the previous night and were premedicated in the operation theatre with pentazocine and atropine intramuscularly $45-70$ minutes prior to the induction. Anaesthesia was induced with pentazocine, thiopentone sodium and muscle paralysis was produced using suxamethonium. Airway was secured with either endotracheal tube or laryngeal mask airway. IPPV was given using $\mathrm{N}_{2} \mathrm{O}: \mathrm{O}_{2}$ mixture, facilitated by the non-depolarising 
muscle relaxant vecuronium bromide. The heart rate, systolic and diastolic blood pressure was recorded before and after induction, immediately after endotracheal intubation or laryngeal mask insertion and thereafter every one-minute for five minutes and at the tenth minute. The ECG was also monitored throughout the procedures. The rate pressure product was calculated by multiplying the systolic blood pressure and heart rate.

The following are the results obtained in our study. The heart increased by $15.54 \%$ following endotracheal intubation and by $9.91 \%$ following laryngeal mask insertion. The systolic blood pressure showed an increase of $14.13 \%$ in endotracheal group and $4.88 \%$ in laryngeal mask group. The diastolic blood pressure increased by $17.73 \%$ in endotracheal group and $27.27 \%$ in laryngeal mask group. The rate pressure product increased by $31.26 \%$ following endotracheal intubation and $14.20 \%$ following laryngeal mask insertion. The incidence of premature ventricular contraction is $9.09 \%$ following endotracheal intubation and $3.64 \%$ following laryngeal mask airway insertion.

\section{CONCLUSION}

This study shows that a considerably less cardiovascular response is produced by insertion of the laryngeal mask airway compared with direct Laryngoscopy and Endotracheal intubation. The laryngeal mask airway may be useful in situations where the pressor response to Endotracheal intubation should be avoided, for example during induction of anaesthesia in a hypertensive patient.

\section{REFERENCES}

[1] Achola KJ, Jones MJ, Mitchell RWD, et al. Effects of beta-adrenoceptor antagonism on the cardiovascular and catecholamine responses to tracheal intubation. Anaesthesia 1988;43(6):433-6.

[2] Reed AP. The unanticipated difficult airway. Anesthesiology Clinics of North America 1996;14(3):443-69.

[3] Bhatt SB, Kendall AP, Lin ES, et al. Resistance and additional inspiratory work imposed by the laryngeal mask airway. A comparison with tracheal tubes. Anaesthesia 1992;47(4):343-7.

[4] Braude N, Clements EA, Hodges UM, et al. The pressor response and laryngeal mask insertion A comparison with tracheal intubation. Anaesthesia 1989; 44(7): 551-4.

[5] Bucx MJ, Scheck PA, van Geel RT, et al. Measurement of forces during laryngoscopy. Anaesthesia 1992; 47(4):348-51.

[6] Bucx MJ, van Geel RT, Scheck PA, et al. Cardiovascular effects of forces applied during laryngoscopy. The importance of tracheal intubation. Anaesthesia 1992; 47(12): 1029-33.
[7] Derbyshire DR, Chmielewski A, Fell D, et al. Plasma catecholamine responses to tracheal intubation. $\mathrm{Br} \mathrm{J}$ Anaesth 1983;55(9):855-60.

[8] Barash PG, Kopriva CJ. The rate-pressure product in clinical anesthesia: Boon or Bane? Anesthesia \& Analgesia 1980;59(4):229-31.

[9] Benumof JL. Laryngeal mask airway. Indications and contraindications. Anesthesiology 1992;77(5):843-6.

[10] Denlinger JK, Ellison N, Ominsky AJ. Effects of intratracheal lidocaine on circulatory responses to tracheal intubation. Anesthesiology 1974;41(4): 409-12.

[11] Hickey S, Cameron AE, Asbury AJ. Cardiovascular response to insertion of Brain's laryngeal mask. Anaesthesia 1990;45(8):629-33.

[12] Fusciardi J, Godet G, Bernard JM, et al. Role of fentanyl and nitroglycerine and haemodynamic response associated with laryngoscopy and tracheal intubation in patients undergoing operations of short duration. Anesth Analg 1986;65(6):617-24.

[13] Low JM, Harvey JT, Prys-Roberts C, et al. Studies of anaesthesia in relation to hypertension. VII: adrenergic responses to laryngoscopy. $\mathrm{Br} \mathrm{J}$ Anaesth 1986; 58(5):471-7.

[14] Shribman AJ, Smith G, Achola KJ. Cardiovascular and catecholamine responses to laryngoscopy with and without tracheal intubation. Br J Anaesth 1987; 59(3): 295-9.

[15] Watcha MF, White PF, Tychsen L, et al. Comparative effects of laryngeal mask airway and endotracheal tube insertion on intraocular pressure in children. Anesth Analg 1992;75(3):355-60.

[16] Ghignone M, Quintin L, Duke PC, et al. Effects of clonidine on narcotic requirements and hemodynamic response during induction of fentanyl anesthesia and endotracheal intubation. Anesthesiology 1986; 64(1): 36-42.

[17] Takeshima K, Noda K, Higaki M. Cardiovascular response to rapid anesthesia induction and endotracheal intubation. Anesth Analg 1964;43:201-8.

[18] Smith JE. Heart rate and arterial pressure changes during fibreoptic tracheal intubation under general anaesthesia. Anaesthesia1988;43(8):629-32.

[19] Menkhaus PG, Reves JG, Alvis JM, et al. Attenuation of heart rate response to intubation by a new betaadrenergic blocking drug, esmolol. Anesthesiology 1984;61(3A):A20. 